\title{
STATUS OF CORAL REEFS IN THE WATER OF SPERMONDE, MAKASSAR, SOUTH SULAWESI
}

\author{
Ni Wayan Purnama Sari ${ }^{1 *}$, Rikoh Manogar Siringoringo ${ }^{1}$, Muhammad Abrar ${ }^{l}$, Risandi Dwirama Putra ${ }^{2}$, Raden \\ Sutiadi ${ }^{3}$, Syafyudin Yusuf $f^{4}$ \\ ${ }^{1}$ Research Center for Oceanography, Indonesian Institute of Sciences, 14410, Jakarta \\ ${ }^{2}$ Technic Faculty, Institute of Maritime Raja Ali Haji, Tanjung Pinang, 29411, Indonesia \\ ${ }^{3}$ Center for the Utilization and Innovation of Science and Technology, Indonesian Institute of Sciences, Cibinong, \\ 16911, Indonesia \\ ${ }^{4}$ Faculty of Marine Science and Fisheries, Hasanuddin University, Makassar, 90245, Indonesia
}

\begin{abstract}
Observations of the condition of coral reefs have been carried out in Spermonde waters from 2015 to 2018. The method used in this observation uses Underwater Photo Transect (UPT), and the data obtained is analyzed using CPCe (Coral Point Count with Excel Extensions) software. The results show that the percentage of coral cover has increased from year to year. The percentage of live coral cover in 2015 was $19.64 \%, 23.60$ in $2016,23.72 \%$ in 2017 , and $27.83 \%$ in 2018 . The increase in live coral cover from year to year is thought to occur due to the availability of nutrients. or increasing public awareness, considering this location is one of the most famous tourist attractions in Makassar. Coral reef health index values can be used to classify coral reef health. Through the analysis of the coral reef health index, an index value of 4 was obtained, which means that the condition of the coral reefs is in the "moderate" category.
\end{abstract}

\section{Introduction}

Indonesia's coral reefs have the highest diversity globally, which makes Indonesia's coral reefs a prime target for research, protection, and management (Mora et al., 2003). In general, diversity decreases as you move away from the center of diversity. However, the heterogeneous distribution of species makes it difficult to define actual boundaries between regions (Hoeksema \& Putra, 2003; Wallace et al., 2003). The high diversity of coral reefs is caused by factors both high alpha (local) and high beta (changes in species composition among many locations) diversities (Tuomisto et al., 2003). Sulawesi Island and its surroundings have the highest coral reefs in Indonesia and are known as the global center of coral reefs with the highest diversity (Suharsono et al., 2011). Sulawesi is also famous as the center of the world's coral triangle. Borderless coral reefs border Sulawesi's coastline, while further offshore is the deep sea with very clear water originating from Arlindo. This results in very dense coral reef growth (Suharsono et al., 2011).

Makassar is the busiest city in eastern Indonesia. As the busiest city, anthropogenic activities like trade and tourism are massive, coupled with port development and reclamation activities. Spermonde waters are a famous tourist site that also functions as a research site for coral reefs (Hoeksema, 1988). Spermonde waters show heterogeneous habitats and are very rich in coral species (Hoeksema, 2007). However, Spermonde waters are experiencing rapid development of water tourism, especially diving and snorkeling activities. Furthermore, there are also river flows that carry the flow of material from land activities. The resulting high sedimentation reduces the ability of light to penetrate the waters and, over a longer period, can cause coral death. The effect of heavy sedimentation on coral reef structure is related to coral reef structure, slow coral growth, and limited coral recruitment (James et al., 2005).

The availability of more complete and comprehensive data can provide information about the condition and biodiversity of coral reefs in Spermonde waters. The data and information needed include the condition and biodiversity of coral reefs. Percentage of hard coral cover and reef fish diversity are important indicators of the potential of the water area and indications of disturbances in the environment (Siswantoro et al., 2005). Information regarding pressure indications on coral reef ecosystems in waters is also important for coral reef management (Suharsono, 2016) (Muller et al., 2012). This study aims to determine the distribution and cover of hard corals in Spermonde Waters to conduct sustainable management of coral reef ecosystems.

\section{Methodology}

\subsection{Time and Location}

Monitoring activities in Spermonde waters were carried out from 1 May to 12 May 2018. The research location 
is in the Spermonde Islands, Makassar City, South Sulawesi.

The distribution of research stations is in all small and charred islands in the waters of the Spermonde Archipelago. Coral reef observations were carried out at 13 station points. The location for observing coral reefs is presented in Figure 1 below. The coordinates of the research location are presented in Table 1.

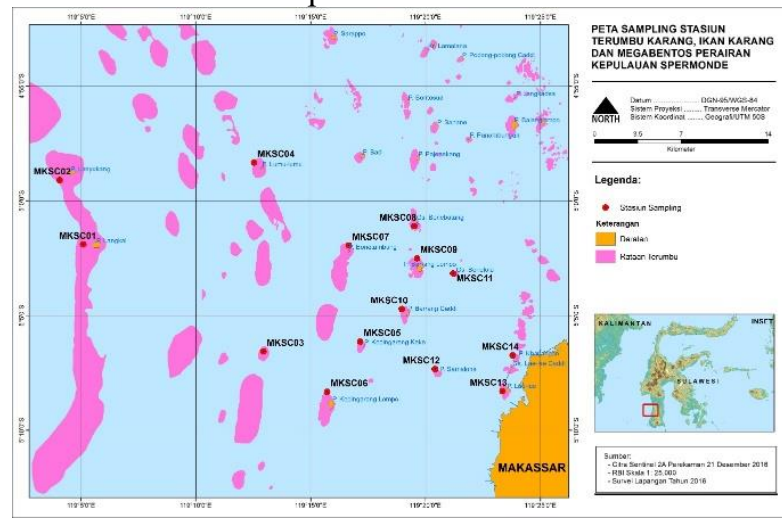

Figure 1. Location of coral reef ecosystem monitoring station

Table 1. Coordinate position of coral reef observation station

\begin{tabular}{|c|c|c|c|}
\hline Location & Year & Lon & Lat \\
\hline Langkai Island & 2018 & 119,0850 & $-5,0316$ \\
\hline Lanyukang Island & 2018 & 119,0678 & $-4,9849$ \\
\hline Gosong Batulabua & 2018 & 119,2158 & $-5,1094$ \\
\hline Lumu-lumu Island & 2018 & 119,2089 & $-4,9722$ \\
\hline $\begin{array}{l}\text { Kodingareng Keke } \\
\text { Island }\end{array}$ & 2018 & 119,2860 & $-5,1022$ \\
\hline $\begin{array}{l}\text { Kodingarenglompo } \\
\text { Island }\end{array}$ & 2018 & 119,2620 & $-5,1388$ \\
\hline $\begin{array}{l}\text { Bonetambung } \\
\text { Island }\end{array}$ & 2018 & 119,2777 & $-5,0323$ \\
\hline $\begin{array}{l}\text { Gosong } \\
\text { Bonebatang } \\
\end{array}$ & 2018 & 119,3253 & $-5,0184$ \\
\hline $\begin{array}{l}\text { Barranglompo } \\
\text { Island }\end{array}$ & 2018 & 119,3272 & $-5,0417$ \\
\hline $\begin{array}{l}\text { Barrangcaddi } \\
\text { Island }\end{array}$ & 2018 & 119,3163 & $-5,0786$ \\
\hline Gosong Bonelola & 2018 & 119,3534 & $-5,0528$ \\
\hline Samalona Island & 2018 & 119,3403 & $-5,1222$ \\
\hline Kayangan Island & 2018 & 119,3967 & $-5,1123$ \\
\hline
\end{tabular}

\subsection{Methods}

Free visual observation is carried out starting from the mainland/coastal coast to the waters, where monitoring activities are carried out at each station equipped with documentation of photos. The main data collection in the form of live coral cover was carried out using the UPT (Underwater Photo Transect) method (Giyanto et al., 2010; Giyanto, 2012a; Giyanto, 2012b). In principle,
UPT is a method of collecting live coral cover data using a frame measuring $58 \mathrm{~cm} \mathrm{x} 44 \mathrm{~cm}$, which is mounted on a $50 \mathrm{~m}$ long transect line by shooting which will then be analyzed through the CPCE application. Data retrieval using the UPT method was carried out with the SCUBA diving technique, using a Canon Powershot G16 camera equipped with a housing that is compatible with diving activities and a square-shaped iron frame that is given a striking color.

The transect line installation follows point 0 of the permanent transect that was installed in the previous year or the last year of monitoring. The point 0 of the permanent transect can be identified based on the coordinates and is marked with two white buoys and two tied iron stakes. If point 0 has been found, then a $50 \mathrm{~m}$ long roll meter is ready to be placed following the old transect line, which usually uses a nangsi rope. The position of the transect line is parallel to the shoreline at a depth where coral is common, at a depth of about 5-7 $\mathrm{m}$. When laying the tape measure, the island's mainland position is on the left. After the tape measure was placed, shooting was carried out along the transect line from the $1 \mathrm{st}$ meter to the 50 th meter with a $1 \mathrm{~m}$ between photos. Shooting at the 1 st meter (frame 1), 3rd meter (frame 3), and the next frame with odd numbers is done to the right of the transect line, while for frames with even numbers (frame 2, frame 4, and so on) are taken to the left of the transect line. Each shooting is carried out at a distance of about $60 \mathrm{~cm}$ from the base of the substrate, so the area of each shooting frame is about $2500 \mathrm{~m} 2$. The illustration of taking photos is shown in Figure 2 below.

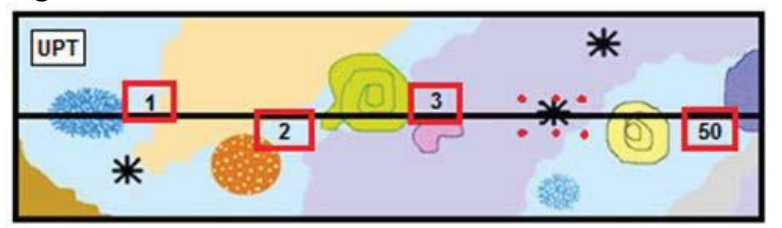

Figure 2. Illustration of taking photos using the UPT method.

\subsection{Data Analysis}

Analysis of the photos taken using a computer and software (software) CPCe (Kohler \& Gill, 2006). A total of 30 random point samples were selected for each photo frame, and each point was coded according to the code of each category and the biota and substrates located at that random point (Table 1).

Table 2. Biota and substrate codes

\begin{tabular}{|c|c|}
\hline Code & Information \\
\hline $\mathrm{LC}$ & Live Coral $=$ Live coral $=\mathrm{AC}+\mathrm{NA}$ \\
\hline$-\mathrm{AC}$ & Acropora $=$ Acropora genus of rock \\
\hline - NA & $\begin{array}{l}\text { Non Acropora }=\text { stony corals other than } \\
\text { the Acropora genus }\end{array}$ \\
\hline DC & Dead Coral $=$ dead coral \\
\hline DCA & $\begin{array}{l}\text { Dead Coral with Algae }=\text { dead coral that } \\
\text { has been overgrown with algae }\end{array}$ \\
\hline $\mathrm{SC}$ & Soft Coral $=$ soft coral \\
\hline SP & Sponge $=$ sponge \\
\hline
\end{tabular}




\begin{tabular}{ll}
\hline FS & Fleshy Seaweed = alga \\
OT & Other Fauna $=$ other fauna \\
R & Rubble $=$ coral shards \\
S & Sand $=$ sand \\
SI & Silt $=$ mud \\
RK & Rock $=$ rock \\
\hline
\end{tabular}

Furthermore, the percentage of cover for each category of biota and substrate for each photo frame is calculated using the formula:

Category Cover Percentage $=$

the number of points of the category number of random dots

x $100 \%$

Based on the percentage value of live coral coverage, it can be determined the condition of coral reefs such as the grouping carried out by the Oceanographic Research Center - Indonesian Institute of Sciences (Puslit Oceanografi-LIPI), which is presented in Table 3 below.

Table 3. Grouping of coral reef conditions based on the percentage value of live coral cover

\begin{tabular}{c|c}
\hline Living Coral Cover (\%) & Assessment Criteria \\
\hline $75-100$ & Very Good \\
$50-74,9$ & Good \\
$25-49,9$ & Pretty Good \\
$0-24,9$ & Not Good \\
\hline
\end{tabular}

\section{Results and Discussion}

\subsection{Overview of Coral Reef Condition}

Coral reefs in Spermonde Waters are a large group of barrier reefs (Molengraaff, 1929) called Sangkarang coral reefs (De Neve, 1982). Clusters of coral reefs in the Spermonde Waters are arranged in parallel (Vuuren, 1920) and are divided into four zones arranged from north to south (Hutchinson, 1945; Hoeksema, 1990). The coral reefs in the Spermonde Islands have a width of $40 \mathrm{~km}$ offshore. The first zone or the deepest zone parallel to the coast is limited to $20 \mathrm{~m}$ to the middle of the sea. The second zone is about 5 to $12.5 \mathrm{~km}$ offshore with a maximum depth of up to $30 \mathrm{~m}$. The third zone is about 12.5 to $30 \mathrm{~km}$ offshore with varying depths from 30 to $50 \mathrm{~m}$. The outermost zone or the Barrier Reef Zone is 30 to $40 \mathrm{~km}$ off the coast of Makassar City. In the east of this zone the depth ranges from 40 to $50 \mathrm{~m}$, while in the west this zone is a drop with a depth of up to $100 \mathrm{~m}$. The monsoon is the main factor influencing the geomorphology and orientation of coral reefs in Spermonde waters (Umbgrove, 1930). The wind blows most strongly during the northwest monsoon season because the southeast monsoon is weakened by the mountains on the mainland.

\subsection{Description and Condition of Coral Reefs at Observation Station}

\subsubsection{Langkai Island}

This observation station is located on the west side of Langkai Island which is included in the administrative area of Sangkarang District, Makassar City. This island is the small outermost island of the Spermonde Archipelago. Sandy beaches with vegetation generally coconut plants and natural coastal vegetation, especially from trees and shrubs. This small island is densely populated. The water area is a fishing ground for local fishers, but there is no policy for managing the water area. Very open water conditions. Coral reefs are included in the type of fringing reef. The reef flat is very wide, with a length of about $500 \mathrm{~m}$ from the coast. Sandy bottom substrate and hard substrate of coral lime. The coral reefs are quite clear at a depth of $6 \mathrm{~m}$. Characteristics of the reef slope are very gentle with a slope of 30 degrees. The observation transect was on the reef flat at a depth of $6.1 \mathrm{~m}$. Living corals are generally massive Porites corals, Dipsastraea groups and Acropora tabulate corals. Commonly found reef association biota include soft coral, blue starfish Linckia sp., and Crinoid sea lilies. Based on the analysis results, the value of coral reef cover in this location is $14.08 \%$. This means that the coral reefs are in the category of poor condition.

\subsubsection{Lanyukang Island}

This observation station is located on the west-south side of Lanyukang Island, Sangkarang District, Makassar City. This island is also the small outermost island of the Spermonde Archipelago. White sandy beaches, land vegetation generally in the form of beach pine and natural coastal vegetation, especially from groups of trees and shrubs and a few coconut trees. This island is an inhabited island which is the location of local fishermen's settlements. There is an easily recognizable sign, namely a lighthouse. Its territorial waters are local fishermen's fishing grounds, and there is no policy for managing its territorial waters. Very open water conditions. Coral reefs are included in the type of fringing reef. The reef flat is very wide, with a width of about $1000 \mathrm{~m}$ from the coast. The bottom substrate of the waters is dominated by live coral, especially from massive groups of Porites and Dipsastraea corals and sandy bottoms. The coral reefs are quite clear at a depth of 9-10 m. Characteristics of the reef slope are very gentle with a slope of 30 degrees. The observation transect was on the reef flat at a depth of $6.1 \mathrm{~m}$. Live corals are generally massive corals, Porites and Dipsastraea, branching corals, Acropora tabulata, and Pocillopora. Commonly found reef association biota include soft corals, Ascidians, and Crinoid sea lilies. Based on the analysis results, the value of coral reef cover in this location is $41.67 \%$. This means that the coral reefs are in a fairly good condition category.

\subsubsection{Gosong Batulabua}

This observation station is a Batulabua charred rock (Bone Lenggang). This station is close to the waters of Kodingarenglompo Island, Sangkarang District, Makassar City. This charred location is a fishing location for local fishers. The waters are very open. 
Coral reefs belong to the patch reef type, the bottom substrate of the reef flat is dominated by the soft coral cover, especially from the Sinularia group, hard substrates and dead coral debris. The observation transect was on the reef flat at a depth of $6.6 \mathrm{~m}$. Live corals are generally from the massive Porites coral group and the Dipsastraea group and the Pocillopora submassive coral group. Commonly found coral association biota include soft corals, Ascidians, and Crinoid sea lilies. Based on the results of the analysis, the value of coral reef cover in this location is $28.40 \%$. This means that the coral reefs are in a fairly good condition category.

\subsubsection{Lumu-lumu Island}

This observation station is located on the west side of Lumu-lumu Island, Sangkarang District, Makassar City. The island is very small and densely populated. The coast has white sandy beaches, which are community ports and homes for residents. This island has a fairly dense local fishing settlement. The water area is a fishing ground for local fishers and there is no policy for the management of the water area. The waters are very open. Coral reefs are included in the type of fringing reef. The characteristics of the reef flat are quite extensive. The permanent transect position is about $1000 \mathrm{~m}$ from the beach. The bottom substrate of the waters on the reef flat is dominated by a fairly dense live coral cover, especially from branching corals Acropora and sheet corals Montipora. The coral reefs are quite clearly visible at a depth of 5-6m. The characteristics of the reef slopes are rather steep with a slope ranging from 60-75 degrees. The observation transect was on the reef slope at a depth of $6.6 \mathrm{~m}$ and moved to a depth of $13.3 \mathrm{~m}$ at a point of $50 \mathrm{~m}$. Coral growth to a depth of $20 \mathrm{~m}$ after that only found white sand. Living corals in this location generally come from the Montipora sheet coral group, Acropora branching corals and free living corals from the Fungiidae family. You can see a lot of dead coral fragments, and the growth of turf algae is quite high. Commonly found associations of coral reef biota include Crinoid sea lilies, sponges, and AscidianTunicata. At this location found turtles and blue spotted stingrays. Based on the analysis results, the value of coral reef cover in this location is $58 \%$. This means that the coral reefs are in the category of good condition.

\subsubsection{Kodingarengkeke Island}

This observation station is located on the north-west side of Kodingarengkeke Island, which is included in the administrative area of Sangkarang District, Makassar City. The island is quite small with white sandy beaches and very sparse land vegetation, but there are a few pine trees and natural vegetation from shrubs. Kodingareng Keke Island is a small uninhabited island. There is a building for tourist facilities in the one-story building in the middle of the island. This location is a fishing area for local fishermen and one of the most famous marine tourism destinations besides Samalona Island. Very open water conditions. Coral reefs are included in the type of fringing reef. The reef average is quite wide. The permanent transect position is about $700 \mathrm{~m}$ from the beach. The bottom substrate of the waters is dominated by sand and broken dead coral, and live coral. Live coral groups are generally from the Fungiidae family group which are spread quite densely on the bottom of the waters. The coral reefs are quite clearly visible at a depth of $6 \mathrm{~m}$. Characteristics of the slope is slightly gentle with a slope of 30-40 degrees. The observation transect was on the reef flat at a depth of about $8.7 \mathrm{~m}$. Common reef association biota include soft corals, Crinoid sea lilies and Ascidian-Tunicata. Based on the analysis results, the value of coral reef cover in this location is $47.07 \%$. This means that the coral reefs are in a fairly good condition category.

\subsubsection{Kodingarenglompo Island}

This observation station is located on the north side of Kodingarenglompo Island, which is included in the administrative area of Sangkarang District, Makassar City. The island is quite small, with white sandy beaches. Vegetation on land is quite rare, generally in the form of natural vegetation from tree groups in coastal areas. This island is densely populated with water areas which are the fishing grounds for local fishermen. The condition of the waters is an open location. Coral reefs are included in the type of fringing reef. The reef flat is quite wide, the permanent transect position is about $600 \mathrm{~m}$ from the coast. The bottom substrate of the reef flat waters was dominated by live coral cover from branching Acropora groups and massive Porites, slightly sandy and dead coral debris. The slope of the coral reef can be seen quite clearly at a depth of about $5 \mathrm{~m}$ with a slope ranging from 30-40 degrees. The observation transect was on the reef slope at a depth of $7.9 \mathrm{~m}$. Live corals are generally branched corals Acropora, massive corals Porites and corals from the family Faviidae and solitary corals from the family Fungidae. Commonly found reef association biota include soft corals, Crinoid sea lilies, Gorgonian and Ascidian-Tunicata. Based on the analysis results, the value of coral reef cover in this location is $25.40 \%$. This means that the coral reefs are in the category of poor condition.

\subsubsection{Bonetambung Island}

This observation station is located on the north side of Bonetambung Island, which is included in the administrative area of Sangkarang District, Makassar City. It is a small, densely inhabited island. The beach is white sand, the vegetation looks quite sparse, generally in the form of coconut plants and coastal vegetation from groups of trees. The water area is a fishing ground for local fishermen because traps were found at a depth of $14 \mathrm{~m}$. The waters are very open. Coral reefs are included in the type of fringing reef, with a fairly broad average, extending north-south. The permanent transect position is about $400 \mathrm{~m}$ from the beach. The bottom substrate of the waters is a reef flat which is dominated by hard substrates of dead coral, sandy and a small 
amount of live coral cover from massive Porites type corals. The coral reef is at a depth of $6 \mathrm{~m}$. The slope of the reef is rather steep with a slope of 45 degrees. The observation transect was on the reef flat at a depth of $11.6 \mathrm{~m}$. Live corals generally come from the massive coral groups Porites and Faviidae. Common reef association biota include Crinoid sea lilies, Holothuria and Ascidian-Tunicata. Based on the analysis results, the value of coral reef cover in this location is $8.53 \%$. This means that the coral reefs are in the category of poor condition.

\subsubsection{Gosong Bonebatang}

This station is located on the south side of Gosong Bonebatang which is included in Sangkarang District, Makassar City. The waters are very open. The expanse of sand is no longer visible so there are no visible signs of nature. Coral reefs are included in the type of coral reef (patch reef). The average is quite wide extending in a north-south direction. The permanent transect position is to the south of the coral reef. There is an overdraft with a depth of about $3 \mathrm{~m}$ on the edge of the reef. The bottom substrate of the reef flat waters is dominated by live coral cover from the branched Porites group and the bottom is sandy and there are many dead coral fractures. The coral reefs are at a depth of 2-3 m. The reef slopes are very gentle with a slope of 20-30 degrees to a depth of $7 \mathrm{~m}$. The observation transect is located on the edge of the reef at a depth of $2.6 \mathrm{~m}$. The live corals at this station are dominated by Porites branching corals, Pavona sheet corals, solitary corals from the Fungia group. Commonly found reef association biota include Crinoid sea lilies, Diadema sea urchins, AscidianTunicata and Isis sp. Based on the analysis results, the value of coral reef cover in this location is $41.03 \%$. This means that the condition of coral reefs is in a fairly good category.

\subsubsection{Baranglompo Island}

This observation station is located on the north-west side of Baranglompo Island which is included in the administrative area of Sangkarang District, Makassar City. This island is the most densely populated island. From the information received, this island is a sea cucumber collecting center for eastern Indonesia so that many people switch professions from fishermen to sea cucumber collectors. At the time of observation, a fisherman was also found looking for sea cucumbers using basic diving equipment. This island is a densely populated island which can be seen from the number of houses and public facilities such as mosques and health centers. On this island there is also a marine research station belonging to Hasanudin University. The island has white sand beaches, the vegetation is generally natural coastal vegetation from groups of trees. The water area is a location for local fishermen to catch. Coral reefs are included in the type of fringing reef, the average is quite wide extending from north to south. The position of the permanent transect is about $300 \mathrm{~m}$ north of the island and is on the edge. The bottom substrate of the reef flat waters was dominated by live coral cover from massive groups of Porites corals and branching corals Pocillopora and Seriatopora. There are sandy sections and hard substrates derived from dead coral. The coral reef is at a depth of $6 \mathrm{~m}$ with a rather steep slope of the reef with a slope of 45 degrees. The observation transect was on the reef slope at a depth of $6 \mathrm{~m}$. The live corals generally come from the massive Porites coral group, the Seriatopora branching coral, the Pocillopora submassive coral group and the Fungiidae free living coral group. Common reef association biota include Crinoid sea lilies, sea anemones, Holothuria and Ascidian-Tunicata. Based on the analysis results, the value of coral reef cover in this location is $27.73 \%$. This means that the condition of coral reefs is in a fairly good category.

\subsubsection{Barangcaddi Island}

This observation station is located on the north-west side of Barrangcaddi Island which is in the administrative area of Sangkarang District, Makassar City. This island is a small inhabited island. White sandy beach, part of which is made of wave dams. Vegetation is very sparse with only a few coconut plants and natural vegetation of tree clusters. The water area is a location for local fishermen to catch. Very open water conditions. Coral reefs are included in the type of fringing reef with a fairly wide average extending north-south. The permanent transect position is about $800 \mathrm{~m}$ from the beach. The bottom substrate of the waters was dominated by hard substrate from dead coral and live coral cover from the massive Porites coral group and Isopora submassive coral and Acropora tabulate coral. The coral reef is at a depth of 3 to $4 \mathrm{~m}$ with a slope of about 45 degrees. The observation transect was on the reef slope at a depth of $7.5 \mathrm{~m}$. Live corals are generally tabulated corals Acropora, massive corals of Porites and Faviidae groups, submassive corals of Isopora and Pocillopora, and free living corals of Fungiidae. Common reef association biota include soft corals, Crinoid sea lilies, Holothuria and Ascidian-Tunicata. Based on the analysis results, the value of coral reef cover in this location is $18.40 \%$. This means that the condition of coral reefs is in the poor category.

\subsubsection{Gosong Bonelola}

This observation station is located on the charred rock of Bonelola, which is included in the administrative area of Sangkarang District, Makassar City. These waters are an open area. There is only a pillar of iron which is a sign of the location of the charred coral. The coral reefs at this location are of the patch reef type with a not-toowide average. The position of the observation transect was in the reef flat area at a depth of $3.7 \mathrm{~m}$. The bottom substrate of reef flat waters is dominated by sandy bottoms and dead coral debris. Live coral cover from submassive group Isopora and massive group Porites, tabulate coral Acropora and blue coral Heliopora. The coral reefs are at a depth of $5 \mathrm{~m}$ with rather steep conditions with a slope of about 45 degrees to a depth of 
$15 \mathrm{~m}$. The live corals are generally tabulate coral Acropora, massive coral Porites and Faviidae, submassive coral Isopora, blue coral Heliopora and free living coral from the Fungiidae group. Common reef association biota include Diadema sea urchins, Crinoid sea lilies, sponges, Gorgonian and Ascidian-Tunicata sea fans. Based on the analysis results, the value of coral reef cover in this location is $29.53 \%$. This means that the condition of coral reefs is in a fairly good category.

\subsubsection{Samalona Island}

This observation station is located on the north-west side of Samalona Island which is included in the administrative area of Sangkarang District, Makassar City. The island is white sandy, the vegetation is generally natural coastal vegetation from groups of trees and herbaceous plants vines on the ground surface. The water area is a fishing ground for local fishermen and is the main marine tourism destination in Spermonde Waters. Coral reefs are classified as fringing reef types with a not too wide average. The permanent transect position is about $300 \mathrm{~m}$ from the beach. The bottom substrate of the waters is dominated by a sandy bottom and a hard substrate of dead coral. Live corals were found from the branching coral group Acropora and free living coral Fungiidae. Coral reef at a depth of 3-5 m with rather steep conditions on a slope of 40-50 degrees. The observation transect was on the reef slope at a depth of $6 \mathrm{~m}$. Live corals are generally in the form of branching corals Acropora and free living corals Fungiidae. Common associated biota include soft corals, sea lilies, Holothuria and Ascidian-Tunicata. Based on the results of the analysis, the value of coral reef cover in this location is $13.74 \%$. This indicates that the condition of coral reefs is in the poor category.

\subsubsection{Kayangan Island}

This observation station is located on the north-west side of Kayangan Island, which is included in the administrative area of Sangkarang District, Makassar City. Kayangan Island is privately owned and developed as an uninhabited tourist island and is very close to the mainland of Makassar City. There is a wave barrier on the beach. Vegetation is very sparse, mostly natural coastal vegetation from groups of trees and cypresses. The territorial waters are the shipping trajectories and ship anchors in and out of the Makassar City port. The waters are a bit open. The water conditions are quite cloudy with a horizontal visibility of 4-5 m more. The coral reefs at this location are classified as fringing reefs with a relatively small reef flat. The permanent transect position is about $500 \mathrm{~m}$ from the beach. The bottom substrate of reef flat waters is dominated by a sandy bottom with high sedimentation and a hard substrate of dead coral. Sloping reef slopes with a slope of about 30 degrees. The observation transect was on the reef slope at a depth of $3.8 \mathrm{~m}$. The live corals found generally came from the massive Porites coral group and the Faviidae coral group and the Mussidae submassive coral group. Many Holothuria were found attached to the sponge as a coral association biota. Based on the analysis results, the value of coral reef cover in this location is $8.20 \%$. This indicates that the condition of coral reefs is in the poor category

\subsection{Temporal Live Coral Cover (2015, 2016, 2017 and 2018)}

The condition of coral reefs is temporally defined as changes in the cover of live coral and other benthic reefs at the same location over a certain period of time. The results of monitoring live coral cover in Spermonde waters are presented in Figure 2 below.

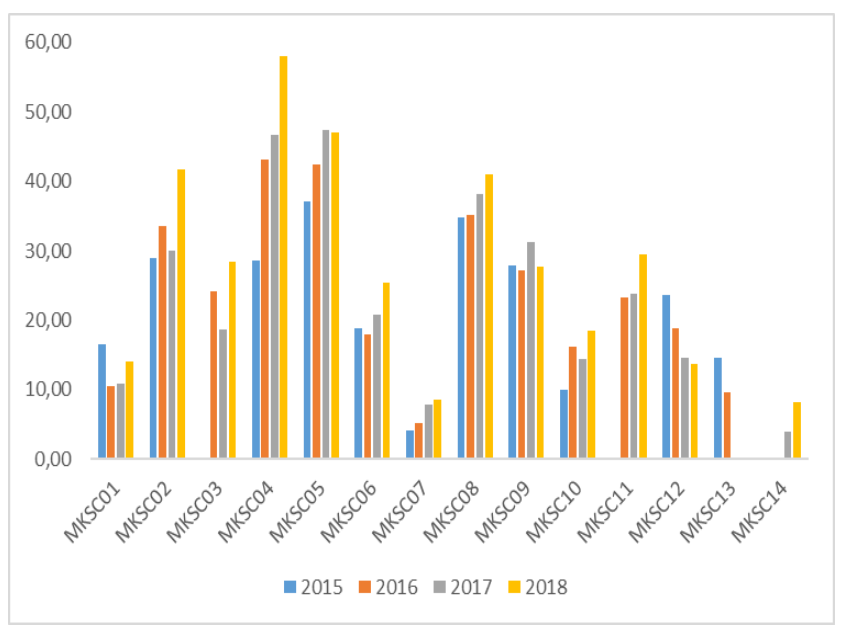

Figure 2. Value of live coral cover in Spermonde waters in 2015, 2016, 2017 and 2018

From Figure 2 above, it can be seen that the value of coral cover at several stations has increased and decreased for a period of 4 years. A total of 10 stations from 13 stations experienced an increase in coral cover. The range of the increase in the value of live coral cover at each of these stations was between $0.66 \%$ to $11.60 \%$, where coral on Lanyukang Island experienced the highest increase in live coral cover of $11.60 \%$. On the other hand, as many as 3 stations experienced a decrease in the range of $0.31 \%$ to $3.54 \%$. Barranglompo Island experienced the highest coral cover decline of $3.54 \%$. The average value of live coral cover in Spermonde waters in 2018 was $27.83 \%$. The average value of live coral cover in 2018 increased by $4.11 \%$ from 2017 , so that the condition of coral reefs in Spermonde Waters is included in the fairly good category. Live coral cover values and other reef benthic categories are presented in Table 4 below. 
Table 4. Live coral cover values and other benthic categories at each station

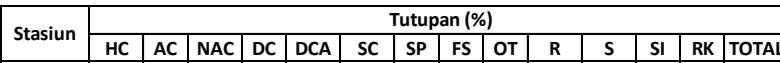
\begin{tabular}{llllllllllllll|lllllllll}
\hline MKSC01 & 14,08 & 1,77 & 12,31 & 0,00 & 33,54 & 0,68 & 1,02 & 0,00 & 0,68 & 5,17 & 44,83 & 0,00 & 0,00 & 100,00 \\
\hline
\end{tabular}

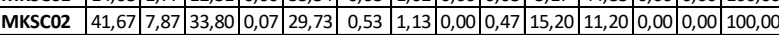
\begin{tabular}{|l|lll|l|lll|lllllll}
\hline MKSCO2 & 41,67 & 7,87 & 33,80 & 0,07 & 29,73 & 0,53 & 1,13 & 0,00 & 0,47 & 15,20 & 11,20 & 0,00 & 0,00 & 100,00 \\
\hline MKSC03 & 28,40 & 0,20 & 28,20 & 0,00 & 26,60 & 14,73 & 4,80 & 0,07 & 7,53 & 11,80 & 6,07 & 0,00 & 0,00 & 100,00 \\
\hline
\end{tabular}

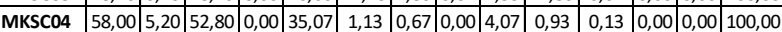

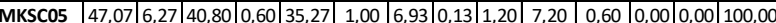

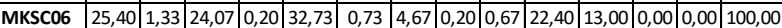

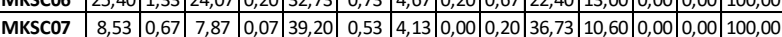
\begin{tabular}{l|l|l|l|l|l|llllllllllllll}
\hline MKSC08 & 41,03 & 0,27 & 40,76 & 0,00 & 19,48 & 0,13 & 1,20 & 0,00 & 3,34 & 23,82 & 11,01 & 0,00 & 0,00 & 100,00 \\
\hline
\end{tabular} \begin{tabular}{llllllllllllllllllllll}
\hline MKSC09 & 27,73 & 2,20 & 25,53 & 0,00 & 49,27 & 0,07 & 0,93 & 0,53 & 0,20 & 16,67 & 4,60 & 0,00 & 0,00 & 100,00
\end{tabular} \begin{tabular}{l|lllllllllllllllll}
\hline MKSC10 & 18,40 & 1,67 & 16,73 & 0,00 & 33,73 & 1,27 & 3,00 & 0,27 & 1,53 & 30,13 & 11,67 & 0,00 & 0,00 & 100,00 \\
\hline
\end{tabular} \begin{tabular}{llllllllllllllllllll}
\hline MKSC11 & 29,53 & 2,80 & 26,73 & 0,00 & 31,00 & 0,80 & 1,67 & 0,00 & 0,27 & 30,73 & 6,00 & 0,00 & 0,00 & 100,00 \\
\hline
\end{tabular} \begin{tabular}{llllllllllllllll}
\hline MKSC12 & 13,74 & 4,80 & 8,94 & 0,00 & 55,77 & 0,00 & 8,07 & 0,20 & 5,60 & 12,07 & 4,54 & 0,00 & 0,00 & 100,00 \\
\hline
\end{tabular}

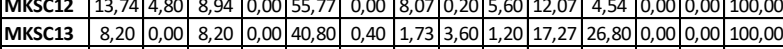

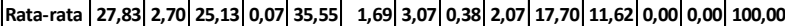
From the table above, it is known that the value of live coral cover (HC) in Spermonde waters ranges from $8.20 \%$ to $58 \%$ with poor to good conditions. The high cover value was also indicated by the category of dead coral covered with algae (DCA) which ranged from $19.48 \%$ to $55.77 \%$. Lumu-lumu Island Station had the highest live coral cover observed this year.

Kayangan Island Station and Bonetambung Island Station this year remained the stations with the lowest coral cover at $8.20 \%$ and $8.53 \%$, respectively, and had relatively high DCA compared to other stations. Bonetambung Island Station is a densely populated island and its waters are fishing grounds for local fishers. While Kayangan Island is a private island managed for tourism needs. The very low live coral cover at both sites was made possible by many factors. Based on information from local residents, Bonetambung Island had become a fishing location that was not environmentally friendly with bombing practices in the previous year which caused low coral cover in this location. The same thing is shown at the Pulau Kayangan station which is a tourist island and very close to the mainland. The water condition on this island is very cloudy due to high sedimentation and is a shipping route for ships to and from the port of Makassar City. The turbidity of the water caused by high sedimentation from the land causes the penetration of light into the water to be hampered so that the coral growth process will also be hampered (Xiubao et al., 2012). This was exacerbated by reclamation activities for the construction of ports and housing which began at the end of 2017. However, an increase in live coral cover was seen at both stations, one of which was because the practice of fishing with bombs and poison had begun to decrease.

\subsection{Distribution and Richness of Coral Genus}

The distribution and richness of coral genus can be calculated from the presence and number of genera in a certain area. The results of the inventory of coral families and genera along the waters of the Spermonde Islands, Makassar City in 2018 are presented in Figure 19. In general, the types of corals found were not much different from 2017. The total genus of corals found at 14 observation stations reached 64 genera from 16 families. Consisting of 62 genera of the hard coral group (Ordo Scleractinia) and two genera of soft reef-building corals, namely the fire coral Millepora (Family Milleporidae, Order Anthomedusae) and blue coral Heliopora (Family Helioporidae, Order Helioporacea)
(Fig. 3). The number of these genera is categorized as high, which is about $75.6 \%$ of the total 82 genera of hard corals in Indonesia (Suharsono, 2010) and $73.8 \%$ of the total 84 genera in the world (Veron, 2000; Spalding, 2007).

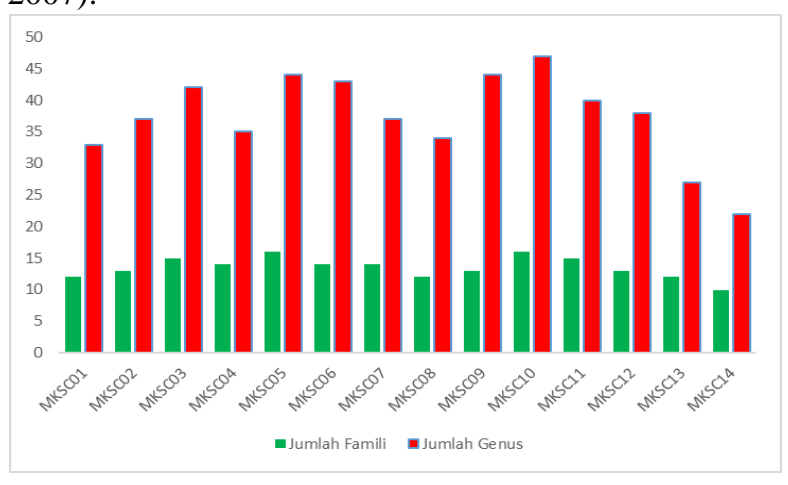

Figure 3. Distribution and richness of reef-building corals in Spermonde waters in 2018

The number of coral genera at each station was quite varied, ranging from $22-47$ genera with an average number of 37 genera and the number of families ranging from 12 - 16 families with an average of 13 families. The most common genera found at each station were Acropora (Acroporidae), Favia and Favites (Favidae), Hydnopora (Merulinidae), Galaxea (Oculinidae), Fungia (Fungiidae) and Pocillopora (Pocilloporidae). Acropora is the most common genus of coral found in Indonesian waters (Veron, 2000; Suharsono, 2010), the most widely distributed with the highest number of species, namely 94 species out of a total of 124 Acropora species in the world (Suharsono, 2010). Likewise, the genus Favia, Favites, Hydnopora, Galaxea and Pocillopora are genera whose species are widely distributed in Indonesian waters (Veron, 2000; Suharsono, 2010). The genus Fungia is generally easy to find in Indonesian waters, but Spermonde waters, in particular, are waters that have the genus Fungia with a very abundant population (Hoeksema, 2012).

The distribution pattern of the number of coral genera appears to be increasing at stations located in the central part of the Spermonde Islands and decreasing at the stations closest and furthest to the mainland coastal city of Makassar. However, the two stations located in the middle, namely Bonetambung Island Station and Gosong Bonebatang Station, still showed a lower number of genera, but still higher than the station closest to the mainland. Likewise, Lumu-lumu Island, although not farthest from the mainland, shows a lower number of genera. The least number of genera are in stations closest to the mainland, including Kayangan Island. Coral growth in this location is limited by the presence of sedimentation from land reclamation activities, freshwater input from the flow of several river estuaries (run off), pollution from factory waste, activities in ports and household waste (Hoeksema, 2012). At the farthest station, the limited number of genera is determined by water conditions such as upwelling, relatively stronger currents and waves (Hoeksema, 2012), as well as high levels of non-environmentally friendly fishery activities 
such as the use of bombs, because they are far from being monitored. The richness of the coral genus in an aquatic area can vary, depending on the physical conditions of the waters, the aquatic environment, human activities and land development in coastal areas and small islands (Susanto, 2010). In addition, biological and ecological factors such as species dominance, interactions and associations of coral reef biota and the limited distribution of certain genera combine with other factors above in determining the richness of coral genus in an area. Unsustainable fisheries activities such as the use of bombs (heard and found evidence of massive coral fractures and dead fish during monitoring) as well as other activities such as tourism, nutrient enrichment from the mainland coast of Makassar have the potential to damage coral reefs and vulnerability to coral biota.

\subsection{Coral reef health index}

Coral reef health index value describes the health of coral reefs in one location. In addition, the value of the coral reef health index is used as a comparative study between one location and another, or in the same location but at different times for observations between time or series, so that data changes can be seen every time.

Based on the analysis of the health index value of coral reefs in Spermonde Waters, the average index value is 4 or is in the medium category. This illustrates that the condition of live coral cover is in the medium category, the potential value of coral recovery is low compared to the value of the coral reef fish category which is also in the low category. Coral health index values at each location are presented in Table 5 below.

Table 5. Coral reef health index value in Central Tapanuli in 2018

\begin{tabular}{lll}
\hline & & Index Value \\
\cline { 3 - 3 } Code & Year & Coral Reef Health \\
\hline MKSC01 & 2018 & 3 \\
\hline MKSC02 & 2018 & 6 \\
\hline MKSC04 & 2018 & 6 \\
\hline MKSC05 & 2018 & 6 \\
\hline MKSC06 & 2018 & 5 \\
\hline MKSC07 & 2018 & 3 \\
\hline MKSC08 & 2018 & 6 \\
\hline MKSC09 & 2018 & 5 \\
\hline MKSC10 & 2018 & 3 \\
\hline MKSC11 & 2018 & 5 \\
\hline MKSC12 & 2018 & 3 \\
\hline
\end{tabular}

\begin{tabular}{lll}
\hline MKSC13 & 2018 & 1 \\
\hline
\end{tabular}

\section{Conclusion}

Based on observations using the Underwater Photo Transect method or independent observations at all observation sites in Spermonde waters, 64 genera of reef-building corals were found, representing 16 families. The percentage of live coral cover was $27.83 \%$ or categorized as "good enough". Rock corals are dominated by massive growth forms as a defense mechanism against a cloudy environment. The dominant corals found were from the families Acropora, Merulinidae and Fungiidae. Massive Fungiidae and Dipsastrea coral groups were most commonly found because these species were able to survive in water conditions with anthropogenic activities or cloudy water conditions

\section{References}

1. Bakus, G. J., (1990) Quantitative Ecology and Marine Biology. Department of Biological Science University of Southern California. Los Angeles. C. A. 90089-0371. A-A. Balkeman/Roterdam. 164 pp.

2. Burke, L., E. Selig \& M. Spalding, 2002. Terumbu Karang Yang Terancam Di Asia Tenggara. World Resource Institute. Washington, DC, USA. 44 pp.

3. Dahuri, R., J. Rais, S. P. Ginting \& M. J. Sitepu. 1996. Pengelolaan Sumber Daya Wilayah Pesisir dan Lautan Secara Terpadu. Jakarta: Pradnya Paramita.

4. Edmund P. Green, Peter J. Mumby, Alasdair J. Edwards \& C. D. Clark. 2000. Remote Sensing Handbook for Tropical Coastal Management. The United Nations Educational, Scientific and Cultural Organization.

5. English, S., C. Wilkinson \& V. Baker. 1997. Survey Manual for Tropical Marine Resources. AIMS. Townsville. 368 pp.

6. Fonseca, M.S. 1987. The management of seagrass system. Trop, Coast, Area. Manag. ICLARM. Newsletter 2 (2): 5-7.

7. Giyanto, Manuputty A.E.W, Abrar M, Siringoringo R.M., Suharti S.R, Wibowo K, Edrus I.N, Arbi U.Y, Cappenberg H.A.W, Sihaloho H.F, Tuti Y. \& Zulfianita D. 2014. Panduan Monitoring Kesehatan Terumbu Karang CRITC COREMAP CTI LIPI: Jakarta. 
8. Giyanto, Winardi, Edi. K., Edward, K., Soeroyo, Anna, E.W.M., Sasanti, R.S., Raden, S. 2006.

Studi Baseline Ekologi Nias. Coral Reef Information and Training Center (CRITC) Coral Rehabilitation and Management Programe (COREMAP) LIPI. Jakarta. 92 hal.

9. Giyanto. 2012a. Kajian Tentang Panjang Transek Dan Jarak Antar Pemotretan Pada Penggunaan Metode Transek Foto Bawah Air. Oseanologi dan Limnologi di Indonesia 38 (1): 1-18.

10. Giyanto. 2012b. Penilaian Kondisi Terumbu Karang Dengan Metode Transek Foto Bawah Air. Oseanologi dan Limnologi di Indonesia 38 (3):377-389.

11. Giyanto; B.H. Iskandar; D. Soedharma \& Suharsono. 2010. Efisiensi Dan Akurasi Pada Proses Analisis Foto Bawah Air Untuk Menilai Kondisi Terumbu Karang. Oseanologi dan Limnologi di Indonesia 36 (1): 111-130.

12. Harvey, J.T. 2008. Abundance Encyclopedia Of Ecology (ed. By S.E.J. Fath and D. Brian), pp. 410. Academic Press. Oxford.

13. Indonesia, K. S. N. R. 2007. Pengelolaan Wilayah Pesisir dan Pulau-Pulau Kecil. ed. K. S. N. R. Indonesia.

14. Jenning, S.B., N.D. Brown \& D. Sheil. 1999. Assessing Forest Canopies And Understorey Illumination: Canopy Closure, Canopy Cover And Other Measures. Forestry 72(1): 59-74.

15. Jompa, D. (editor) 2015. Monitoring Ekosistem Terumbu Karang dan Ekosistem Terkait Kota Makassar. Unhas Coremap-CTI LIPI, Makassar, 51 hal.

16. Jompa, D. dan Suharsono (editors) 2016. Monitoring Ekosistem Terumbu Karang dan Ekosistem Terkait Kota Makassar. Unhas Coremap-CTI LIPI, Makassar, 113 hal.

17. Keppel, T.L. \& M. Abrar. 2013. Kondisi Terumbu Karang Di Kabupaten Nias Dan Kabupaten Simeulue Pasca Satu Tahun Mega Tsunami 2004. Jurnal Segara 9 (1): 13-21.

18. Kohler, K.E. \& M. Gill. 2006. Coral Point Count With Excel Extensions (Cpce): A Visual Basic Program For The Determination Of Coral And Substrate Coverage Using Random Point Count Methodology. Comput Geosci 32(9):1259-1269.
19. Krebs, Ch. J., 1989. Ecological Methodology. Harper \& Row Publ. New York. 678 p

20. Loya Y. 1978. Plotless And Transect Methods. In: Coral Reefs: Research Methods. Stoddart DR, Johannes RE, eds. pp. 197-217. UNESCO, Paris.

21. Mumby, P.J., C. D. Clark, E. P. Green, \& A. J. Edwards. 1998. Benefits of Water Column Correction and Contextual Editing for Mapping Coral Reefs. International Journal of Remote Sensing, Vol. 19, No. 1, pp. 203-210.

22. Obura, D.O. \& Grimsdith, G. (2009). Resilience Assessment Of Coral Reefs - Assessment Protocol For Coral Reefs, Focusing On Coral Bleaching And Thermal Stress. IUCN Working Group On Climate Change And Coral Reefs. IUCN, Gland, Switzerland. $70 \mathrm{pp}$.

23. Odum, E.P., 1971. Fundamental of Ecology. W.B. Saunders co., Philadelphia : 574 pp.

24. Phinn, S. R., C. M. Roelfsema \& P. J. Mumby (2012) Multi-Scale, Object-Based Image Analysis For Mapping Geomorphic And Ecological Zones On Coral Reefs. International Journal of Remote Sensing, 33, 3768-3797.

25. Sari, N.W.P. Rikoh, M.S. Muhammad A., Petrus M., Ucu Y., Alvi., Muhammad H. A. 2017. Monitoring Ekosistem Terumbu Karang dan Ekosistem Terkait Kota Makassar. Unhas Coremap-CTI LIPI, Makassar, 101 hal.

26. Suharsono. 2004. Jenis - Jenis Karang Batu di Indonesia. Pusat Penelitian Oseanografi, Lembaga Ilmu Pengetahuan Indonesia. COREMAP Proyek. 344 hal.

27. Supriharyono. 2002. Pelestarian dan Pengelolaan Sumber Daya Alam di Wilayah Pesisir Tropis. Jakarta: PT Gramedia Pustaka Utama.

28. Susanto, H. A. 2010. Assesment of the Sedimentation Effects on Coral Reefs Using Stable Carbon and Nitrogen Isotopes in Berau, East Kalimantan, Indonesia. Thesis. Graduate School of Social and Cultural Studies Kyushu University. Japan. 139 pp.

29. Xiubao L., H. huang., J. Yang. and F. You. 2012. Surface Sediment Composition as an Indicator of Sedimentation stress and Nutrient Level in Coral reefs. Proc.12th Int. Coral Reefs. Symp. Cairns, Quensland, Australia 